\title{
Light as a Novel Inhibitor of Nitrite-Oxidizing Bacteria (NOB) for the Mainstream Partial Nitrification of Wastewater Treatment
}

\author{
Keugtae Kim ${ }^{1}$ (D) and Yong-Gyun Park ${ }^{2, *}$ \\ 1 Department of Environmental \& Energy Engineering, Suwon University, 17 Wauan-gil, Bongdam-eup, \\ Hwaseong-si, Gyeonggi-do 18323, Korea; kkt38@suwon.ac.kr \\ 2 Pioneer Team, Research Institute, GS E\&C, 33, Jong-ro, Jongro-gu, Seoul 03159, Korea \\ * Correspondence: ygpark01@gsenc.com
}

Citation: Kim, K.; Park, Y.-G.

Light as a Novel Inhibitor of

Nitrite-Oxidizing Bacteria (NOB) for the Mainstream Partial Nitrification of Wastewater Treatment. Processes 2021, 9, 346. https://doi.org/ $10.3390 /$ pr9020346

Academic Editor:

Maria Jose Martin de Vidales

Received: 27 January 2021

Accepted: 10 February 2021

Published: 13 February 2021

Publisher's Note: MDPI stays neutral with regard to jurisdictional claims in published maps and institutional affiliations.

Copyright: (c) 2021 by the authors. Licensee MDPI, Basel, Switzerland. This article is an open access article distributed under the terms and conditions of the Creative Commons Attribution (CC BY) license (https:// creativecommons.org/licenses/by/ $4.0 /)$.

\begin{abstract}
Conventional biological nutrient removal processes in municipal wastewater treatment plants are energy-consuming, with oxygen supply accounting for $45-75 \%$ of the energy expenditure. Many recent studies examined the implications of the anammox process in sidestream wastewater treatment to reduce energy consumption, however, the process did not successfully remove nitrogen in mainstream wastewater treatment with relatively low ammonia concentrations. In this study, blue light was applied as an inhibitor of nitrite-oxidizing bacteria (NOB) in a photo sequencing batch reactor (PSBR) containing raw wastewater. This simulated a biological nitrogen removal system for the investigation of its application potential in nitrite accumulation and nitrogen removal. It was found that blue light illumination effectively inhibited NOB rather than ammonia-oxidizing bacteria due to their different sensitivity to light, resulting in partial nitrification. It was also observed that the NOB inhibition rates were affected by other operational parameters like mixed liquor suspended solids (MLSS) concentration and sludge retention time (SRT). According to the obtained results, it was concluded that the process efficiency of partial nitrification and anammox (PN/A) could be significantly enhanced by blue light illumination with appropriate MLSS concentration and SRT conditions.
\end{abstract}

Keywords: blue light; NOB inhibition; mainstream; AOB; light intensity

\section{Introduction}

Biological nitrogen removal (nitrification and denitrification) from municipal wastewater (MWW) has become a critical process in wastewater treatment plants over the past decades. In conventional biological nitrogen removal systems, aeration is essential for nitrification and organic oxidation and accounts for $45 \%$ to $75 \%$ of the energy consumption of wastewater treatment plants (WWTPs) [1]. In recent years, reducing energy consumption with high nutrient removal efficiency has become a significant issue in the design and operation of WWTPs. Therefore, the concept of the mainstream partial nitritation and anammox $(\mathrm{PN} / \mathrm{A})$ processes is gaining more attention for nitrogen removal because the nitrogen present in the liquid fraction can be treated autotrophically with three unique and potential advantages: (i) $\sim 60 \%$ reduction of oxygen demand for partial oxidation of ammonium to nitrite, (ii) nearly 100\% elimination of carbon demand for denitrification, and (iii) $80 \%$ reduction of excess sludge [2,3]. For the development of an effective mainstream PN process, nitrite-oxidizing bacteria (NOB) inhibition parameters, such as sludge retention time (SRT), dissolved oxygen (DO) concentration, aeration pattern, aeration duration, temperature, substrate concentration, inhibitors, and growth kinetics have been studied [4-6]. However, the possibility of mainstream PNs targeting MWW influent containing low ammonia concentration has not been intensively investigated, despite experimental and operational evidence of MWW plants, which indicates the success of sidestream PN targeting a high 
ammonia concentration. The main issues of the mainstream PN process are related to (i) low nitrogen concentrations, (ii) variable nitrogen loads, (iii) low temperatures, (iv) stringent wastewater quality requirements, and (v) long-term process stability [7].

The $\mathrm{N}$ cycle consists of various nitrogen types $\left(\mathrm{NO}_{3}{ }^{-}, \mathrm{NO}_{2}{ }^{-}\right.$, dissolved organic nitrogen, etc.). Its concentration and distribution in water are affected by physical, chemical, and biological factors. For example, concentration changes of $\mathrm{NO}_{2}{ }^{-}$have often been found in stratified oceans. A primary $\mathrm{NO}_{2}{ }^{-}$maximum (PNM) occurs in stratified water columns when $\mathrm{NO}_{2}{ }^{-}$production exceeds its consumption [8]. Over the past decades, the mechanisms of $\mathrm{NO}_{2}{ }^{-}$accumulation resulting in PNMs in stratified open-oceanic water columns have been studied. Two main mechanisms, such as photoinhibition of nitrifying bacteria and $\mathrm{NO}_{2}{ }^{-}$release by phytoplankton, were found $[8,9]$. The first mechanism involves the separated oxidation of $\mathrm{NH}_{4}{ }^{+}$and $\mathrm{NO}_{2}{ }^{-}$during the nitrification process. This results in the accumulation of $\mathrm{NO}_{2}{ }^{-}$when the microbial populations, such as ammonia-oxidizing bacteria $(\mathrm{AOB})$ and $\mathrm{NOB}$, have different sensitivities to light or different substrate demands within the water column $[10,11]$. The second mechanism involves the process of generating $\mathrm{NO}_{2}{ }^{-}$during incomplete $\mathrm{NO}_{3}{ }^{-}$assimilation when phytoplankton is stressed by light $[8,12,13] . \mathrm{NO}_{2}{ }^{-}$emission in phytoplankton could occur by failing to reduce $\mathrm{NO}_{2}{ }^{-}$ to $\mathrm{NH}_{4}{ }^{+}$when the cell does not receive sufficient light energy [14]. Our previous study found that blue light accumulates nitrite in a sequencing batch reactor (SBR) containing wastewater-borne algal-bacterial consortia and raw wastewater by selective photoinhibition at NOB [15]. The results indicated that blue light could be a new type of NOB inhibition factor.

In this study, blue light was applied to SBR containing raw wastewater to investigate its effects on nitrite accumulation and nitrogen removal. Furthermore, the physiological responses of nitrifying bacteria and the changes in the bacterial community by blue light were also monitored to confirm whether blue light may be a new type of NOB inhibition factor for mainstream, partial nitritation.

\section{Material and Methods}

\subsection{Characteristics of Raw Wastewater}

This study used raw wastewater from the S. municipal wastewater treatment plant in Suwon, Republic of Korea. Its characteristics are presented in Table 1. The raw wastewater was taken from a primary settling tank within the plant, and then filtered using a $75 \mu \mathrm{m}$ drum screen to remove debris. The resulting wastewater had a composition similar to general municipal wastewater $\left(99.2 \%\right.$ of TKN $\left(57.9 \%\right.$ of $\left.\mathrm{NH}_{4}{ }^{+}-\mathrm{N}\right)$ in $\left.\mathrm{TN}\right)$.

Table 1. Characteristics of raw wastewater ( $\mathrm{mg} / \mathrm{L} \pm \mathrm{SD})$.

\begin{tabular}{cccccccc}
\hline BOD $_{5}$ & SS & TN & TKN & $\mathbf{N H 4}^{+}-\mathbf{N}$ & NO $_{\mathbf{x}}{ }^{-}-\mathbf{N}$ & TP & Alk. \\
\hline 243.2 & 185.2 & 72.7 & 72.1 & 42.1 & 0.3 & 5.9 & 179.5 \\
\pm 68.1 & \pm 33.2 & \pm 26.4 & \pm 26.2 & \pm 20.5 & \pm 0.2 & \pm 0.6 & \pm 28.2 \\
\hline
\end{tabular}

\subsection{Experimental Procedures}

Experiments with Batch Reactors-To confirm the occurrence of partial nitrification, batch tests were conducted with two reactors: A photo batch reactor (PBR) and a batch reactor (BR), which was made of an acrylic cylinder (internal diameter of $13 \mathrm{~cm}$, height of $20 \mathrm{~cm}$, and effective volume of $2 \mathrm{~L}$ ). Both reactors contained activated sludge, and they were agitated mechanically at $150 \mathrm{rpm}$ using an impeller, as presented in Figure 1. The PBR was illuminated by blue light to evaluate its effect on partial nitrification, but the BR was operated without blue light illumination as a control system. The blue light was provided by two LED sticks with $100 \mu \mathrm{mol} \mathrm{m} \mathrm{m}^{-2} \mathrm{~s}^{-1}$ of light intensity, and air was continuously provided at a rate of $0.1 \mathrm{vvm}$ (volume to volume per minute). The MLSS concentration achieved during the experiments was $1800 \mathrm{mg} / \mathrm{L}$. The temperature, $\mathrm{pH}$, and conductivity were $25^{\circ} \mathrm{C}, 7.2$, and $425.3 \mu \mathrm{S} / \mathrm{cm}$, respectively. A sample $(50 \mathrm{~mL})$ was 
collected every $40 \mathrm{~min}$ for measuring $\mathrm{DO}$ and $\mathrm{pH}$, and then filtered using $\mathrm{GF} / \mathrm{C}$ to analyze the concentrations of $\mathrm{NH}_{4}{ }^{+}-\mathrm{N}, \mathrm{NO}_{2}{ }^{-}-\mathrm{N}$, and $\mathrm{NO}_{3}{ }^{-}-\mathrm{N}$.

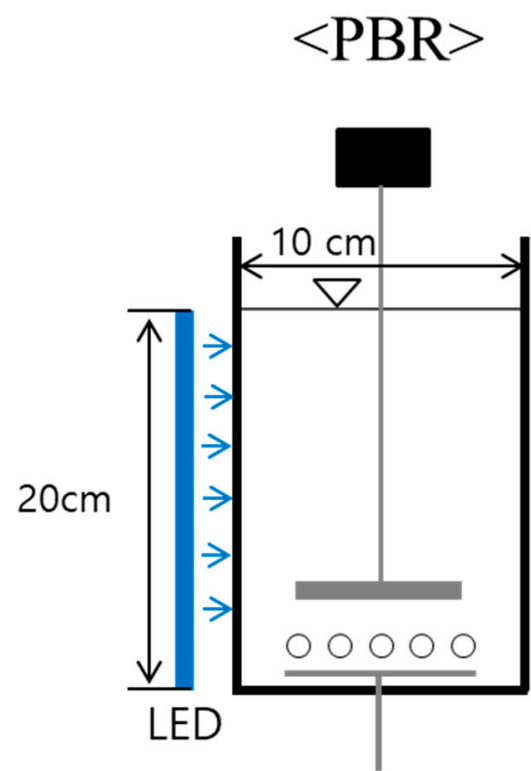

Air

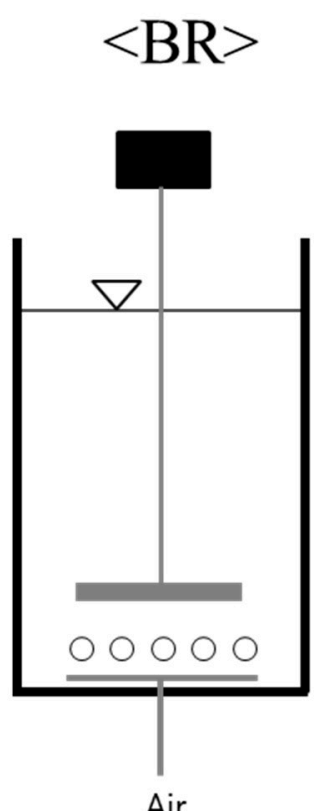

Air

Figure 1. Schematics diagram of the batch test reactors.

Experiments with Sequencing Batch Reactors-A photo sequencing batch reactor (PSBR) and a sequencing batch reactor (SBR) were used for investigating the effects of blue light, MLSS, and SRT on partial nitrification. Similar to the batch reactors, (P)SBRs were made of an acrylic cylinder (internal diameter of $20 \mathrm{~cm}$, height of $40 \mathrm{~cm}$, and effective volume of $6 \mathrm{~L}$ ). Both reactors contained activated sludge and were agitated mechanically at $150 \mathrm{rpm}$ using an impeller, as presented in Figure 2. The PSBR was illuminated by blue light-emitting LEDs at a light intensity of $100 \mu \mathrm{mol} \mathrm{m}{ }^{-2} \mathrm{~s}^{-1}$ with two LED sticks. The SBR was not illuminated by blue light, which was used as a controlled system. They were operated on a six cycle process at room temperature $\left(25^{\circ} \mathrm{C}\right)$. Each cycle consisted of anoxic, oxic, settling, draining, and idle periods, with operation times of $1.5 \mathrm{~h}, 2.5 \mathrm{~h}, 45 \mathrm{~min}, 15 \mathrm{~min}$, and $1 \mathrm{~h}$, respectively. During the oxic stage, air was continuously provided at a rate of $0.1 \mathrm{vvm}$ (volume to volume per minute). Three liters of wastewater were injected into the reactors in the first 9 min of the anoxic stage. The hydraulic retention time (HRT) was $\sim 10 \mathrm{~h}$, and sludge retention time (SRT) ranged from $10 \mathrm{~d}$ to $15 \mathrm{~d}$. The $\mathrm{pH}$ of the reactors varied from 7.0 to 7.5 , and was not controlled in the experiments. The operational conditions of the reactors are presented in Table 2. As an influencing factor of partial nitrification, MLSS and SRT were also investigated in Phases 1, 2, and 3. Meanwhile, a blue light relationship profile test was carried out with the aim of monitoring the behavior of nitrite build-up when stable partial nitrification occurred in the PSBR after 52 days of sludge seeding. A sample $(50 \mathrm{~mL})$ was collected every $30 \mathrm{~min}$ to measure conductivity, $\mathrm{DO}$, and $\mathrm{pH}$, and then filtered using $\mathrm{GF} / \mathrm{C}$ to analyze the concentrations of $\mathrm{NH}_{3}-\mathrm{N}, \mathrm{NO}_{2}{ }^{-}-\mathrm{N}$, and $\mathrm{NO}_{3}{ }^{-}-\mathrm{N}$. 


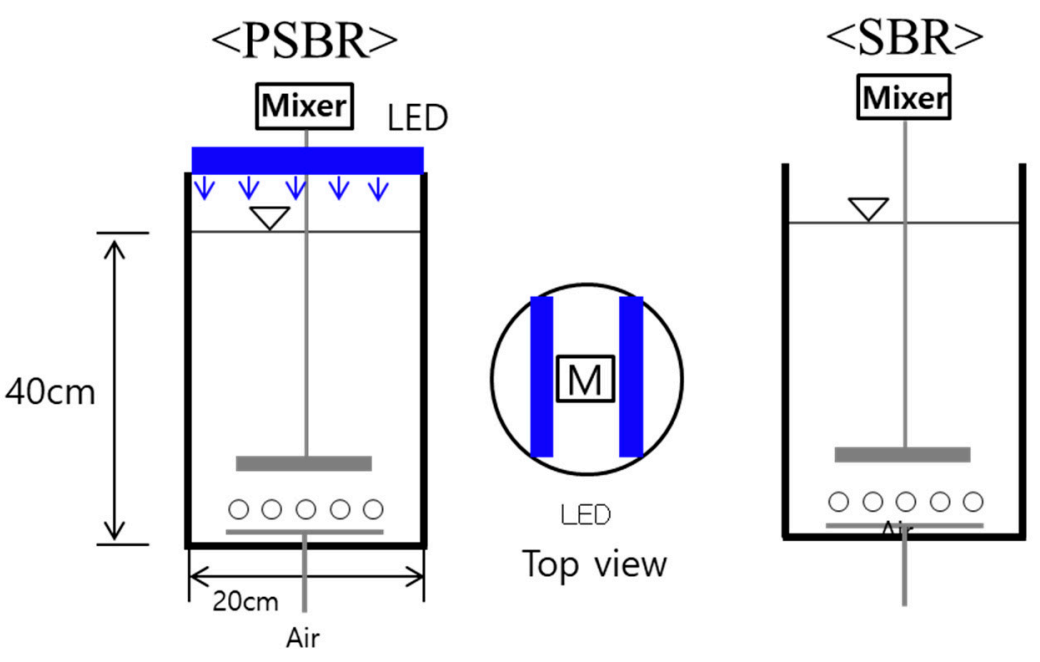

Figure 2. Schematics diagram of the photo sequencing batch reactor (PSBR) and the sequencing batch reactor (SBR).

Table 2. Operational conditions of the (P)SBRs.

\begin{tabular}{cccc}
\hline Category & Operation Condition & \\
& Phase 1 & Phase 2 & Phase 3 \\
\hline MLSS $(\mathrm{mg} / \mathrm{L})$ & $2.500 \pm 215$ & $1.500 \pm 198$ & $1.500 \pm 163$ \\
SRT (days) & 15 & 15 & 10 \\
Blue Light Intensity $\left(\mu \mathrm{mol} / \mathrm{m}^{2} / \mathrm{s}\right)$ & 100 & 100 & 100 \\
\hline
\end{tabular}

\subsection{Analysis}

To analyze the $\mathrm{NO}_{2}{ }^{-}-\mathrm{N}$ build-up status, the water qualities of $\mathrm{BOD}, \mathrm{COD}_{\mathrm{Cr}}, \mathrm{NH}_{4}{ }^{+}-\mathrm{N}$, $\mathrm{NO}_{2}{ }^{-}-\mathrm{N}, \mathrm{NO}_{3}{ }^{-}-\mathrm{N}, \mathrm{pH}$, alkalinity, and MLSS were periodically measured. $\mathrm{NH}_{4}{ }^{+}-\mathrm{N}$, $\mathrm{NO}_{2}{ }^{-}-\mathrm{N}, \mathrm{NO}_{3}{ }^{-}-\mathrm{N}, \mathrm{pH}$, alkalinity, and MLSS were measured every day, and the other parameters, biological oxygen demand (BOD) and chromium chemical oxygen demand $\left(\mathrm{COD}_{\mathrm{Cr}}\right)$, were measured every week following the standard methods [16]. Conductivity, $\mathrm{pH}$, and temperature were measured with a Multipurpose Water Quality Analyzer YSI 550 (YSI, Yellow Springs, OH, USA). An automated water analyzer (QuAAtro 39, SEAL Analytical Ltd., Southampton, UK) was used to analyze the concentrations of $\mathrm{NH}_{4}{ }^{+}-\mathrm{N}$ and $\mathrm{NO}_{\mathrm{x}}{ }^{-}-\mathrm{N}\left(\mathrm{NO}_{2}{ }^{-}-\mathrm{N}+\mathrm{NO}_{3}{ }^{-}-\mathrm{N}\right)$. A photo-radiometer (HD 2102, Delta OHM, Padova, Italy) was used to measure the blue light intensity.

For AOB, NOB, and bacterial community analysis, MLSS samples were collected from both PSBR and SBR at 83 days in Phase 3 . The diversity of the bacterial community was investigated using a previously established 16S rRNA gene-based terminal-restriction fragment length polymorphism (T-RFLP) and cloning-Sanger sequencing methods [17]. Briefly, a piece of bacterial culture was subjected to the Power Soil DNA Isolation Kit (MO BIO Laboratories, Inc., Carlsbad, CA, USA). The extracted DNA was amplified using the primer set targeting bacterial 16S rRNA genes. The bacterial-universal primer 27F (5 GAGTTTGATCMTGGCTCAG 3)/800R (5 TACCAGGGTATCTAATCC 3') were used. PCR reactions were carried out in a 1000 Thermal Cycler (Bio-Rad, Hercules, USA), and then T-RFLP analysis and cloning-Sanger sequencing were performed. Pyro sequencing was performed by a commercial laboratory (Macrogen, Seoul, Korea). The sequence obtained was analyzed at the phylum and family levels. The experiments were repeated for at least three instances. 


\section{Results and Discussion}

\subsection{Effect of Blue Light on Nitrification in Batch Tests}

Batch tests were performed to investigate the application potential of blue light as a new NOB inhibition factor in PBRs with activated sludge. The results were compared with those obtained from other batch tests in BR as a controlled system, which also contained activated sludge, but without blue light illumination. Figure 3 shows the concentration change of $\mathrm{NH}_{4}{ }^{+}-\mathrm{N}, \mathrm{NO}_{2}{ }^{-}-\mathrm{N}$, and $\mathrm{NO}_{3}{ }^{-}-\mathrm{N}$ within the reactors for a period of seven hours. As presented in Figure 3A, the removal rates of $\mathrm{NH}_{4}{ }^{+}-\mathrm{N}$ were not initially significantly different in both PBR and BR (i.e., by less than $100 \mathrm{~min}$ ). The removal rate of $\mathrm{NH}_{4}{ }^{+}-\mathrm{N}$ in BR was relatively linear until it was completely removed. However, the removal rate in the PBR was retarded for experimental periods greater than $300 \mathrm{~min}$. The removal rate of $\mathrm{NH}_{4}{ }^{+}-\mathrm{N}$ was $2.57 \mathrm{mg} / \mathrm{L} / \mathrm{h}$ in the PBR, which was $\sim 20 \%$ less than that in the BR $(3.11 \mathrm{mg} / \mathrm{L} / \mathrm{h})$. The results obtained indicate that nitrification was affected by blue light illumination to the PBR. Merbet et al. (2012) reported that the complete inhibition of nitrite production could be achieved by light. The de novo synthesis of ammonia monooxygenase is required after the culture is exposed to visible light [18]. As shown in Figure 3B,C, the concentration of $\mathrm{NO}_{2}{ }^{-} \mathrm{N}$ accumulated up to almost $20 \mathrm{mg} / \mathrm{L}$, but the concentration of $\mathrm{NO}_{2}{ }^{-} \mathrm{N}$ was maintained to be $1.03 \mathrm{mg} / \mathrm{L}$ in the PBR. Unlike the results obtained in the PBR, $22 \mathrm{mg} / \mathrm{L}$ of $\mathrm{NH}_{4}{ }^{+}-\mathrm{N}$ was completely nitrified to $\mathrm{NO}_{3}{ }^{-}-\mathrm{N}$ after the seven-hour experiment in the BR. As a result, $\mathrm{NO}_{2}{ }^{-}-\mathrm{N}$ did not exist in the reactor, which was generally induced by nitrifier activities. These findings indicate that blue light selectively inhibited NOB. In contrast, $\mathrm{AOB}$ was slightly inhibited, especially at the beginning. This phenomenon can be explained by the main cause of the primary nitrite maximum (PNM) formation in stratified open-oceanic water columns. Many previous studies have reported that light or by-products of microalgae might induce PNM formation. Because the penetration depth of blue light is very deep in the sea with a low SS concentration, the specific light might facilitate PNM formation. The experimental results obtained in this study support how the PNM was formed mainly by blue light. Similarly, it was understood from the experimental results that NOB activity could be selectively retarded by blue light.

(A)

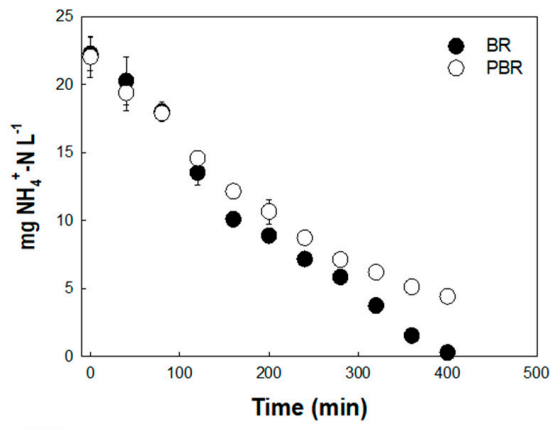

(C)

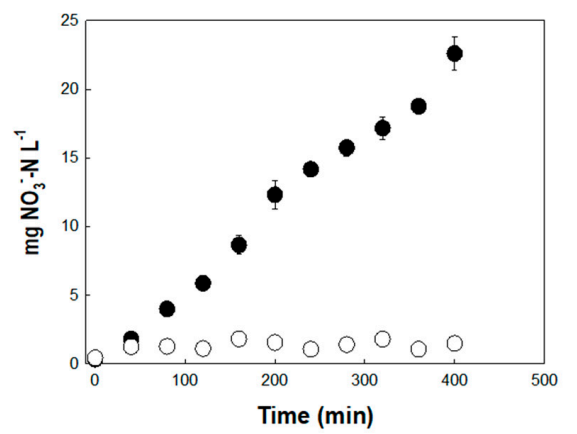

(B)

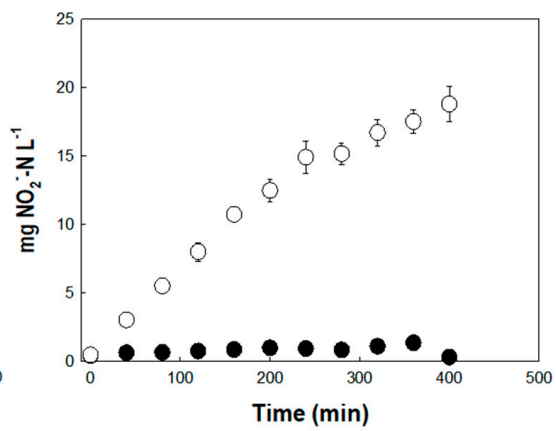

Figure 3. Effects of the blue light on the concentration change of $\mathrm{NH}_{4}{ }^{+}-\mathrm{N}(\mathbf{A}), \mathrm{NO}_{2}{ }^{-} \mathrm{N}(\mathbf{B})$, and $\mathrm{NO}_{3}{ }^{-}-\mathrm{N}(\mathbf{C})$ in the photo batch reactor $(\mathrm{PBR})$ and the batch reactor $(\mathrm{BR})$. 


\subsection{Behavior of Nitrite Build-Up in the PSBR}

The concentration profiles of nitrogen compounds were monitored to understand the characteristics of partial nitrification in the PSBR illuminated by blue light. The PSBR contained raw wastewater with 20 to $40 \mathrm{mg} / \mathrm{L}$ of $\mathrm{NH}_{4}{ }^{+}-\mathrm{N}$, as presented in Table 1. Figure 4 presents the concentration changes of $\mathrm{NH}_{4}{ }^{+}-\mathrm{N}_{1} \mathrm{NO}_{2}{ }^{-}-\mathrm{N}$, and $\mathrm{NO}_{3}{ }^{-}-\mathrm{N}$ in the PSBR illuminated by blue light. The concentration profile test affected by blue light was performed after 52 days of sludge seeding. According to the obtained results, the initial $\mathrm{NH}_{4}{ }^{+}-\mathrm{N}$ concentration increased subsequently to the injection of raw wastewater containing $20 \mathrm{mg} / \mathrm{L}$ of $\mathrm{NH}_{4}{ }^{+}-\mathrm{N}$. After this increase, the $\mathrm{NH}_{4}{ }^{+}-\mathrm{N}$ concentration was steady at $\sim 9 \mathrm{mg} / \mathrm{L}$ in the anoxic stage, which was $\sim 50 \%$ dilution at the start of the experimental operation. It was observed that $\mathrm{NH}_{4}{ }^{+}-\mathrm{N}$ was completely nitrified within $2.5 \mathrm{~h}$ of the oxic stage. Meanwhile, according to the concentration profile test results of $\mathrm{NO}_{2}{ }^{-} \mathrm{N}$, denitrification occurred when the wastewater influent was injected in the anoxic stage. Moreover, the $\mathrm{NO}_{2}{ }^{-}-\mathrm{N}$ build-up increased its concentration up to $10 \mathrm{mg} / \mathrm{L}$ in the oxic stage. Subsequently, $2.5 \mathrm{mg} / \mathrm{L}$ of $\mathrm{NO}_{2}{ }^{-} \mathrm{N}$ was denitrified in the idle stage. The denitrification of $\mathrm{NO}_{2}{ }^{-}-\mathrm{N}$ in the idle stage may be explained by endogenous denitrification, as previously reported [19]. According to the obtained results of $\mathrm{NO}_{3}{ }^{-}-\mathrm{N}$, the concentration was continuously maintained at a low level of $0.5 \pm 0.3 \mathrm{mg} / \mathrm{L}$ in the anoxic stage, $1.8 \pm 0.5 \mathrm{mg} / \mathrm{L}$ in the oxic stage, and $0.5 \mathrm{mg} / \mathrm{L} \pm 0.3$ in the idle stage, respectively. However, nitrite build-up was not observed in SBR, which data are not presented in this paper. The obtained results indicate that blue light can be used as the main influencing factor of mainstream partial nitrification for energy-saving wastewater treatment. Although blue light was first applied to the wastewater treatment process as a NOB inhibition factor in our study, previous studies have been conducted in the metabolic pathway field. Guerrero and Jones (1997) confirmed the presence of c-type cytochrome in both $\mathrm{AOB}$ and $\mathrm{NOB}$ and also found that photoinhibition was directly related to higher absorbance at $408 \mathrm{~nm}$ [20]. Furthermore, NOB is known to be more sensitive to blue light than $\mathrm{AOB}$ when the cell density is great $\left(10^{6}\right.$ cells $\left./ \mathrm{mL}\right)$, and $\mathrm{AOB}$ can recover faster through the intracellular ammonia oxidation metabolic pathway in the presence of large concentrations of $\mathrm{NH}_{3}$ and $\mathrm{NO}_{2}{ }^{-}$[21].

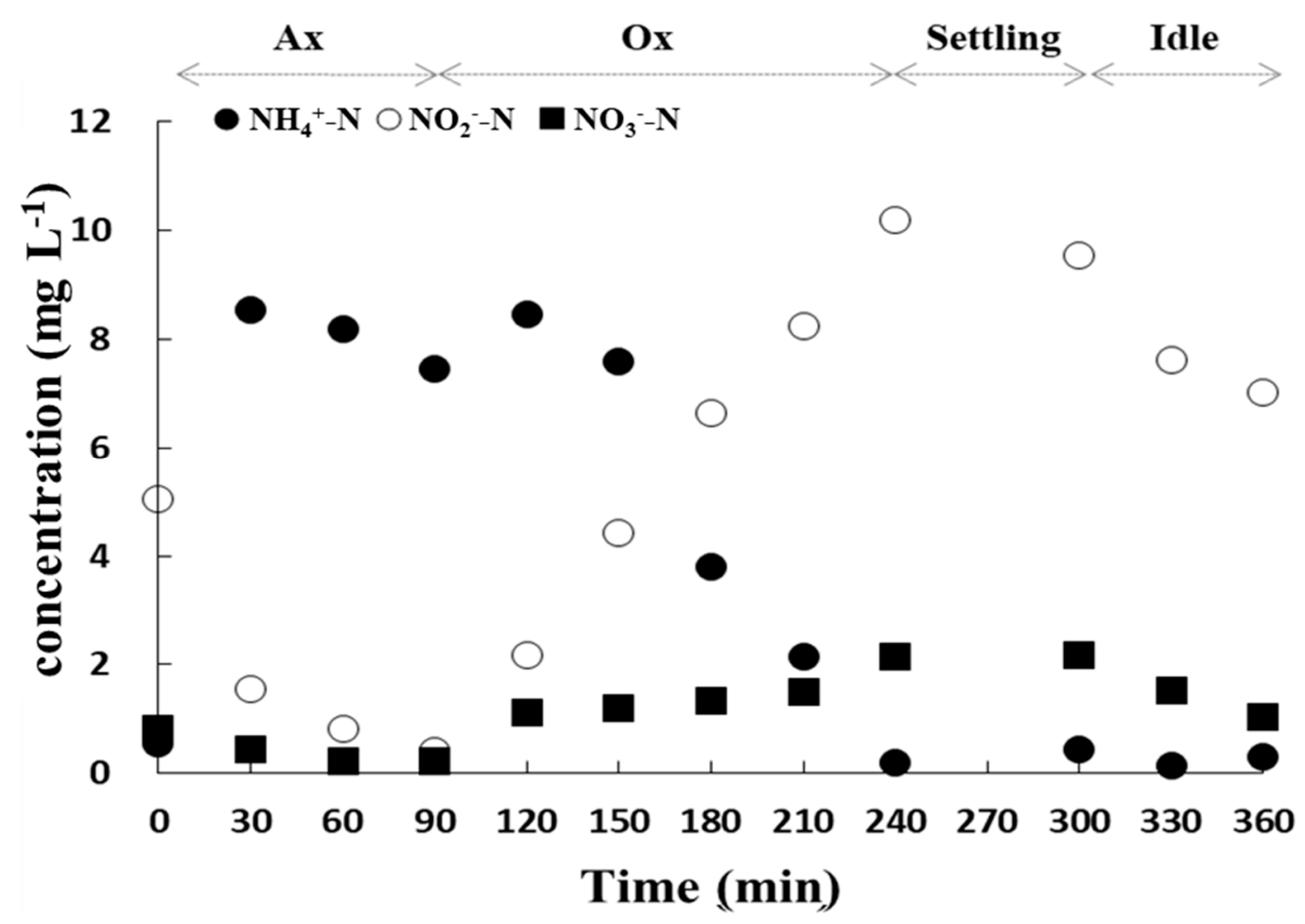

Figure 4. Nitrogen $\left(\mathrm{NH}_{4}{ }^{-}-\mathrm{N}, \mathrm{NO}_{2}{ }^{-}-\mathrm{N}\right.$, and $\left.\mathrm{NO}_{3}{ }^{-}-\mathrm{N}\right)$ behavior in a continuous photo sequencing batch reactor (PSBR). 


\subsection{Effect of MLSS and SRT on Partial Nitrification with Blue Light}

The effects of MLSS and SRT on nitrite build-up (i.e., nitrification and nutrient removal efficiency) were investigated in the PSBR illuminated by blue light, which contained raw wastewater. The experiments were conducted in three phases (i.e., Phases 1, 2, and 3) with different MLSS and SRT (Table 2). The change in the MLSS was used to investigate the shading effect of blue light. The SRT was also changed to study its effect on the growth rates of $\mathrm{AOB}$ and $\mathrm{NOB}$, which consequently affected the partial nitrification. As presented in Figure 5, the $\mathrm{NH}_{4}{ }^{+}-\mathrm{N}$ concentration in the influent water was $42.1 \pm 20.5 \mathrm{mg} / \mathrm{L}$ during the experimental period. After seeding the sludge, the concentration in the effluent water was $6.1 \pm 7.3 \mathrm{mg} / \mathrm{L}$ in Phase 1, $17.6 \pm 9.3 \mathrm{mg} / \mathrm{L}$ in Phase 2, $2.8 \pm 2.1 \mathrm{mg} / \mathrm{L}$ in Phase 3, and $1.6 \pm 0.2 \mathrm{mg} / \mathrm{L}$ in Phase 2, respectively. Here, to reconfirm the effect of SRT on partial nitrification after stable partial nitrification in Phase 3, Phase 3 with SRT of $10 \mathrm{~d}$ was modified to Phase $2^{\mathrm{a}}$ with an SRT of $15 \mathrm{~d}$. The Phase 1 experiment was conducted for $20 \mathrm{~d}$ after sludge seeding to the PSBR, and the MLSS concentration and SRT applied were $2500 \pm 215 \mathrm{mg} / \mathrm{L}$ and $15 \mathrm{~d}$, respectively. It was observed that although the concentration of $\mathrm{NH}_{4}{ }^{+}-\mathrm{N}$ in the PSBR decreased for $10 \mathrm{~d}$ after starting the experimental operation, the nitrification rate was considerably reduced in Phase 1 . However, high nitrification rates were observed in Phase 2, especially in Phase 3, with relatively lower MLSS concentrations and shorter SRT (i.e., $10 \mathrm{~d}$ ). It may be assumed that blue light affected the activity of $\mathrm{AOB}$ at the beginning of the experiment, resulting in the retardation of nitrification. After that period, AOB may have adapted to the blue light illumination and resulted in stable nitrification by the second ammonia oxidation metabolic pathway. As described previously, $\mathrm{AOB}$ is recovered rapidly from photoinhibition using an alternative pathway [21].

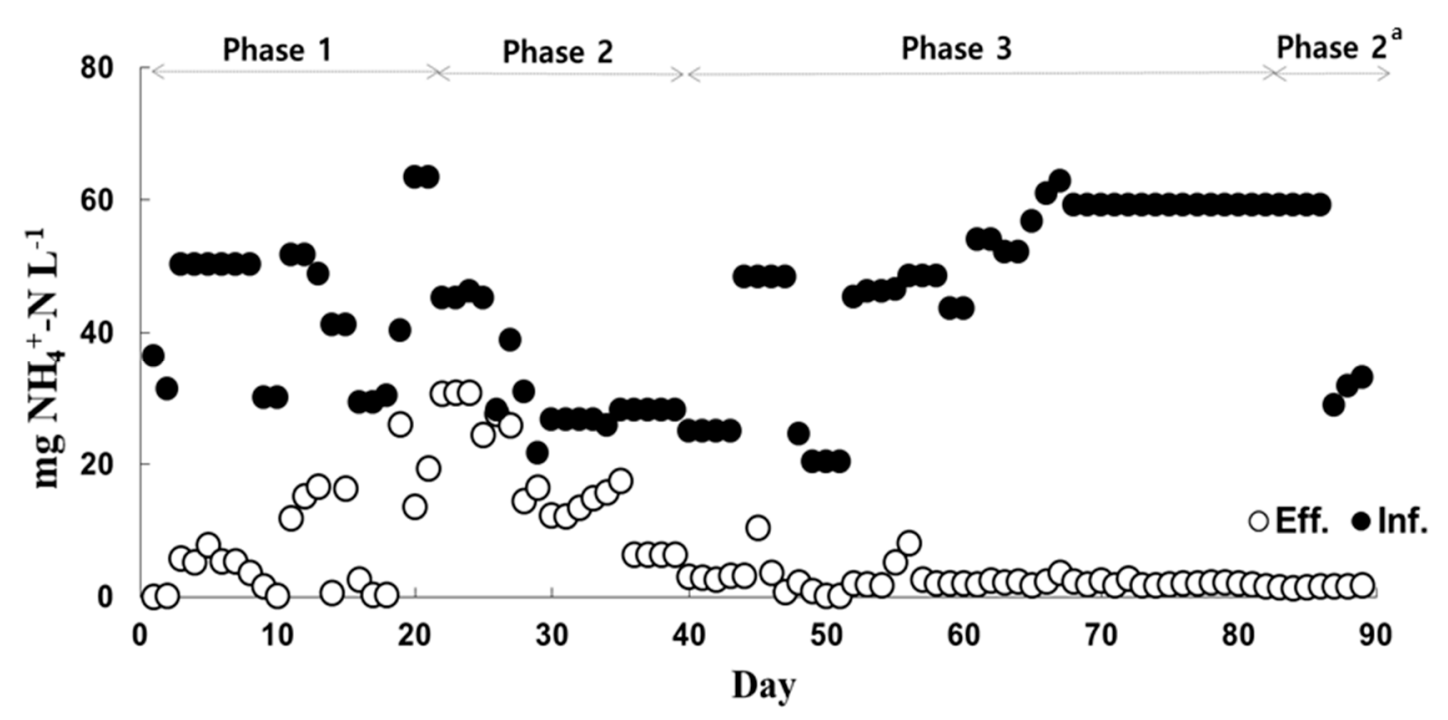

Figure 5. Change of ammonia nitrogen $\left(\mathrm{NH}_{4}{ }^{+}-\mathrm{N}\right)$ concentration.

Figure 6 presents the concentration profiles of $\mathrm{NO}_{2}{ }^{-}-\mathrm{N}$ and $\mathrm{NO}_{3}{ }^{-}-\mathrm{N}$ in the PSBR effluent. The concentration of $\mathrm{NO}_{2}{ }^{-}-\mathrm{N}$ was modified during the experimental phases, $0.6 \pm 0.4 \mathrm{mg} / \mathrm{L}$ in Phase 1, $2.2 \pm 1.0 \mathrm{mg} / \mathrm{L}$ in Phase $2,8.7 \pm 2.3 \mathrm{mg} / \mathrm{L}$ in Phase 3, and $4.9 \pm 2.7 \mathrm{mg} / \mathrm{L}$ in Phase $2^{\mathrm{a}}$. And the concentrations of $\mathrm{NO}_{3}{ }^{-}-\mathrm{N}$ were $8 \pm 2.4 \mathrm{mg} / \mathrm{L}$ in Phase 1, $2.4 \pm 1.6 \mathrm{mg} / \mathrm{L}$ in Phase 2, $1.9 \pm 0.7 \mathrm{mg} / \mathrm{L}$ in Phase 3, and $3.2 \pm 0.9 \mathrm{mg} / \mathrm{L}$ in Phase $2^{\mathrm{a}}$. The nitrite accumulation observed could be explained by two influencing factors: The MLSS causing the shading effect and the SRT affecting the growth rates of $\mathrm{AOB}$ and NOB. First, as the MLSS concentration was reduced from $2500 \pm 215 \mathrm{mg} / \mathrm{L}$ in Phase 1 to $1500 \pm 198 \mathrm{mg} / \mathrm{L}$ in Phases 2 and 3, the nitrite build-up was observed. This phenomenon may be explained by the shading effect of blue light, which is affected by the MLSS concentration. The effect of blue light on NOB inhibition increased at low MLSS concentrations because the contact time of blue light to $\mathrm{AOB}$ and $\mathrm{NOB}$ increased as the 
MLSS concentration decreased. Accordingly, the shading effect decreased, and the nitrite build-up was observed as the MLSS concentration decreased to $1500 \mathrm{mg} / \mathrm{L}$ in the PSBR. Carlos et al. (2017) reported that excessive light may result in photoinhibition, which may cause a loss in biomass productivity. However, the shading effect caused by microalgae concentration, such as MLSS, can decrease photoinhibition caused by excessive light [22]. Second, as the SRT was reduced from $15 \mathrm{~d}$ in Phase 2 to $10 \mathrm{~d}$ in Phase 3, a relatively high nitrite build-up was observed in the reactor. It is known that the maximum growth rate of AOB is higher than that of NOB at mesophilic temperatures $\left(>20^{\circ} \mathrm{C}\right)$, leading to NOB wash-out under low SRT conditions in reactors [23]. Thus, NOB was washed out, and $A O B$ remained in the reactor when the SRT was changed from $15 \mathrm{~d}$ to $10 \mathrm{~d}$ because of the different $\mathrm{AOB}$ and $\mathrm{NOB}$ growth rates. Meanwhile, the nitrite build-up was facilitated because $\mathrm{AOB}$ was dominant in the microbial community compared to NOB by washing out NOB by applying relatively short SRT. Therefore, it was found that blue light, MLSS, and SRT were the main influencing factors for the partial nitrification of raw wastewater with a low $\mathrm{NH}_{3}-\mathrm{N}$ concentration.

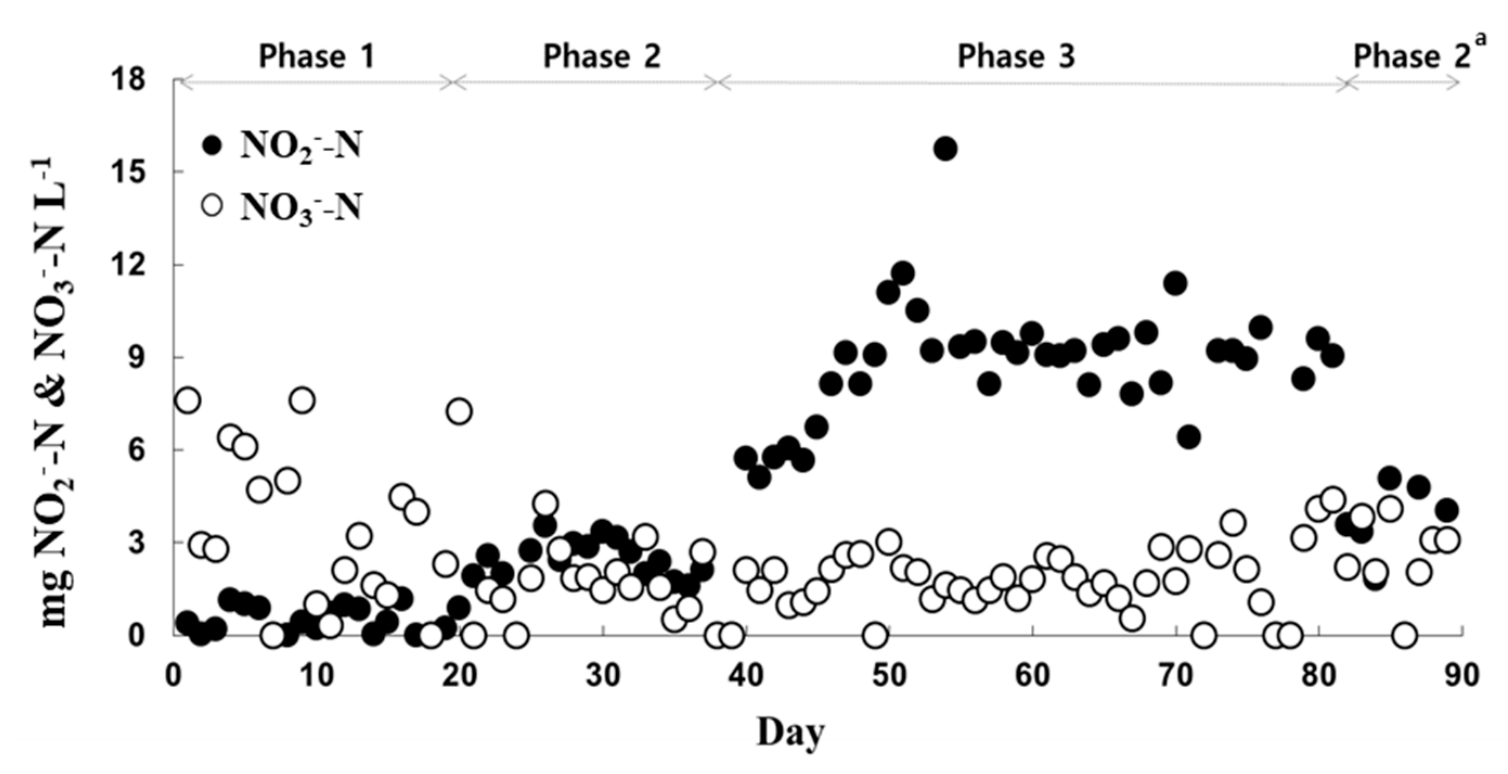

Figure 6. Changes in the concentrations of nitrite nitrogen $\left(\mathrm{NO}_{2}{ }^{-}-\mathrm{N}\right)$ and nitrate nitrogen $\left(\mathrm{NO}_{3}{ }^{-}-\mathrm{N}\right)$.

In contrast, the accumulation rate of $\mathrm{NO}_{2}{ }^{-}-\mathrm{N}$ can be expressed as $\mathrm{NO}_{2}{ }^{-}-\mathrm{N} /\left(\mathrm{NO}_{2}{ }^{-}-\mathrm{N}\right.$ $\left.+\mathrm{NO}_{3}{ }^{-}-\mathrm{N}\right)$. As presented in Figure 7, the accumulation rate for each phase was $16.2 \pm 0.2 \%$ in Phase $1,50.1 \pm 0.2 \%$ in Phase $2,81.4 \pm 0.1 \%$ in Phase 3 , and $58.3 \pm 0.1 \%$ in Phase $2^{\mathrm{a}}$. Stable partial nitrification was induced by blue light, low MLSS, and low SRT in Phase 3. Moreover, it was observed that the ratio of $\mathrm{NO}_{3}{ }^{-}-\mathrm{N}$ was apparently lower in the effluent of Phase 3, which indicates that the NOB inhibition was obviously operated under oxic conditions by blue light. In addition, the denitrification of $\mathrm{NO}_{3}{ }^{-}-\mathrm{N}$ was also performed under the operating conditions of the Idle stage by endogenous denitrification as described profile in this study. As a result, it was determined that the concentration of $\mathrm{NO}_{3}{ }^{-}-\mathrm{N}$ was low in the effluent. According to the obtained results, it was verified that stable $\mathrm{NO}_{2}{ }^{-}-\mathrm{N}$ accumulation could be achieved by the combination of suitable blue light intensity, MLSS, and STR. These results indicate that partial nitrification followed by anammox could be successful for treating mainstream wastewater. 


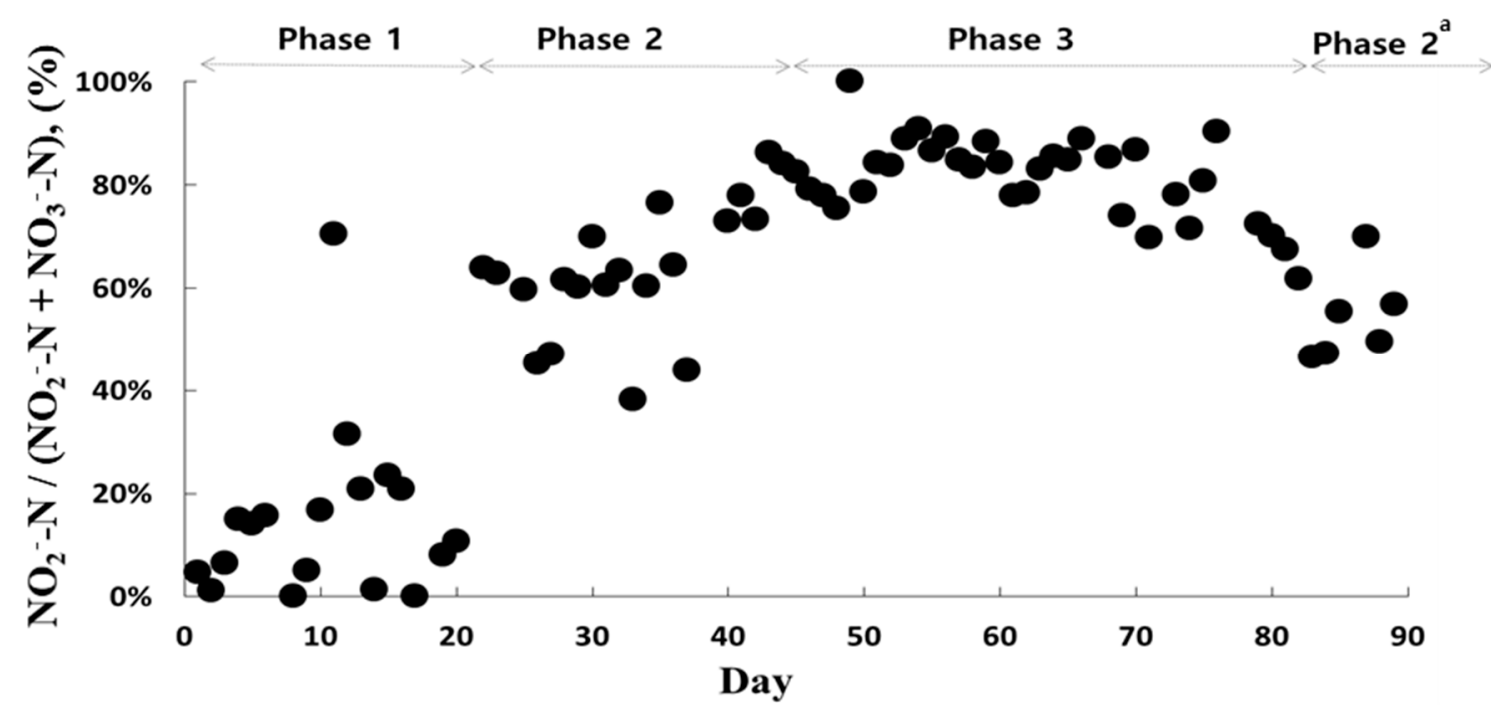

Figure 7. Change in $\mathrm{NO}_{2}{ }^{-}-\mathrm{N}$ accumulation rate $\left(\mathrm{NO}_{2}{ }^{-}-\mathrm{N} /\left(\mathrm{NO}_{2}{ }^{-}-\mathrm{N}+\mathrm{NO}_{3}{ }^{-}-\mathrm{N}\right), \%\right)$.

\subsection{Changes of a Nitrifying Bacteria Community by Blue Light}

The change in the NOB community is a very important factor affecting partial nitrification. The DNA extraction from PSBR and SBR was conducted on the 83 days of the experimental operation of Phase 2 (Figure 8). This was performed to evaluate the change in bacterial communities, including NOB induced by blue light, the analysis of $16 \mathrm{~S}$ rRNA gene sequences of biomass collected from the reactors. These sequences were identified at the family level. The four representative families related to nitrification were Nitrosomonadaceae, Nitrospiraceae, Bradyrhizobiaceae, and Ectothiorhodospiraceae [24]. It has been reported that AOB belonging to the family Nitrosomonadaceae consisted of a monophyletic phylogenetic group within the $\beta$-Proteobacteria [25], and NOB, including Nitrospira and Nitrobacter, belongs to the family Nitrospiraceae and Bradyrhizobiaceae [24,26]. As presented in Table 3 of the NGS data obtained, family Nitrosomonadaceae occupied $0.126 \%$ and $0.379 \%$ in SBR and PSBR, respectively. This indicates that the ratio of AOB was increased by blue light illumination. Meanwhile, the proportion of family Nitrospiraceae changed significantly from $4.840 \%$ for SBR to $0.141 \%$ for PSBR, indicating that NOB was significantly decreased by blue light. Regarding nitrifying bacteria belonging to the family Bradyrhizobiaceae and Ectothiorhodospiraceae, it was not found for unknown reasons in this study. Considering the results obtained, it was concluded that partial nitrification was performed in the reactor because of the relatively dominant AOB community caused by NOB inhibition with blue light. To sum up the NOB inhibition assay, it may be concluded that the appropriate combination of blue light, MLSS, and SRT are important control factors for the sustained mainstream partial nitrification of raw wastewater.

Table 3. Percentiles of nitrifying bacterial community at family level.

\begin{tabular}{|c|c|c|}
\hline Family Percentiles (\%) & PSBR & SBR \\
\hline Nitrosomonadaceae & 0.379 & 0.126 \\
\hline Nitrospiraceae & 0.141 & 4.840 \\
\hline
\end{tabular}

(a) Bacterial communities were analyzed by NGS for biomass obtained at 83 days (Figure 6). 


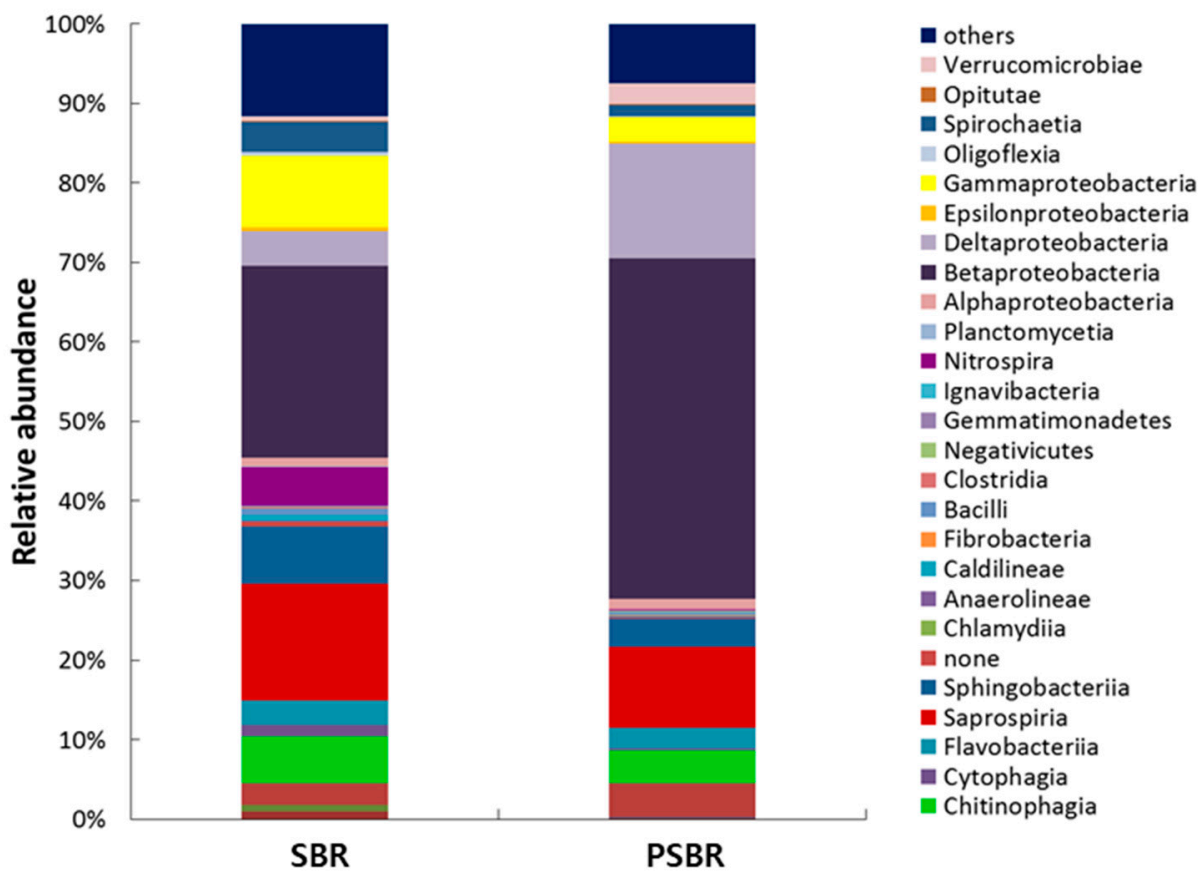

Figure 8. Bacterial communities at the family level of activated sludge in the sequencing batch reactor (SBR) and the photo sequencing batch reactor (PSBR) at the end of cultivation (83 days, Figure 6). Phyla with a mean relative abundance greater than $0.01 \%$ are shown.

\section{Conclusions}

Similar to the primary mechanism of PNM formation in stratified open-oceanic water columns, it was found that the blue light illumination induced nitrification in the PBR and resulted in an $\sim 20 \%$ lower removal rate of $\mathrm{NH}_{4}{ }^{+}-\mathrm{N}$ than that obtained in the BR. In the PBR, there was an accumulation of $\mathrm{NO}_{2}{ }^{-}-\mathrm{N}$, but the concentration of $\mathrm{NO}_{3}{ }^{-}-\mathrm{N}$ did not significantly change. However, $\mathrm{NH}_{4}{ }^{+}-\mathrm{N}$ was completely nitrified to $\mathrm{NO}_{3}{ }^{-}-\mathrm{N}$ in the $\mathrm{BR}$, resulting in a very low level of $\mathrm{NO}_{2}{ }^{-}-\mathrm{N}$ concentration induced by nitrifier activities. The obtained experimental results of the blue light effects on nitrification in the PSBR with blue light illumination resulted in a gradual increase in the concentration of $\mathrm{NO}_{2}{ }^{-}-\mathrm{N}$ up to $10 \mathrm{mg} / \mathrm{L}$ in the oxic stage. Subsequently, $\mathrm{NO}_{2}{ }^{-}-\mathrm{N}$ was denitrified in the idle stage induced by endogenous denitrification. Meanwhile, the concentration of $\mathrm{NO}_{3}{ }^{-}-\mathrm{N}$ was not significantly modified compared to that of $\mathrm{NH}_{4}{ }^{+}-\mathrm{N}$ and $\mathrm{NO}_{2}{ }^{-}-\mathrm{N}$. These results prove that blue light could be used as a significant influencing factor of mainstream partial nitrification in WWTPs because NOB was relatively more sensitive to blue light than AOB, especially in high cell density conditions. In addition, it was found that MLSS and SRT were other important factors influencing nitrification. As the MLSS concentration decreased, the impact of blue light on NOB inhibition increased. By reducing the SRT, a relatively high nitrite build-up was observed because the $\mathrm{AOB}$ growth rate was higher than that of NOB under low SRT conditions. According to the analysis results of the 16S rRNA gene sequences of biomass collected from the PSBR and SBR, the AOB ratio was increased by blue light illumination, however, the NOB significantly decreased. Based on all the results presented and discussed in this study, blue light can be applied for the partial nitrification and anammox processes in mainstream wastewater treatment together with the adjustment of other important operation factors, including MLSS and SRT.

Author Contributions: Investigation K.K.; writing—original draft, K.K. and Y.-G.P.; writing—review \& editing, Y.-G.P. All authors have read and agreed to the published version of the manuscript.

Funding: This research was funded by “Global Top Project (Project No. 20190021900011)”.

Institutional Review Board Statement: Not applicable. 
Informed Consent Statement: Not applicable.

Data Availability Statement: Due to confidentiality agreements, supporting data can only be made available to bona fide researchers subject to a non-disclosure agreement.

Acknowledgments: This work was supported by the Korea Ministry of Environment as "Global Top Project" (Project No. 20190021900011).

Conflicts of Interest: The authors declare no conflict of interest.

\section{References}

1. $\quad$ Liu, X.-W.; Wang, Y.-P.; Huang, Y.-X.; Sun, X.-F.; Sheng, G.-P.; Zeng, R.J.; Li, F.; Dong, F.; Wang, S.-G.; Tong, Z.-H.; et al. Integration of a Microbial Fuel Cell With Activated Sludge Process for Energy-Saving Wastewater Treatment: Taking a Sequencing Batch Reactor As an Example. Biotechnol. Bioeng. 2011, 108, 1260-1267. [CrossRef] [PubMed]

2. Cao, Y.; Van Loosdrecht, M.C.M.; Daigger, G.T. Mainstream Partial nitritation-anammox in Municipal Wastewater Treatment: Status, Bottlenecks, and Further Studies. Appl. Microbiol. Biotechnol. 2017, 101, 1365-1383. [CrossRef] [PubMed]

3. Ge, S.; Peng, Y.; Qiu, S.; Zhu, A.; Ren, N. Complete Nitrogen Removal from Municipal Wastewater via Partial Nitrification by Appropriately Alternating anoxic/Aerobic Conditions in a Continuous Plug-Flow Step Feed Process. Water Res. 2014, 55, 95-105. [CrossRef] [PubMed]

4. Peng, Y.; Zhu, G. Biological Nitrogen Removal With Nitrification and Denitrification via Nitrite Pathway. Appl. Microbiol. Biotechnol. 2006, 73, 15-26. [CrossRef] [PubMed]

5. Aslan, S.; Miller, L.; Dahab, M. Ammonium Oxidation via Nitrite Accumulation under Limited Oxygen Concentration in Sequencing Batch Reactors. Bioresour. Technol. 2009, 100, 659-664. [CrossRef]

6. Yuan, Z.; Oehmen, A.; Peng, Y.; Ma, Y.; Keller, J. Sludge Population Optimisation in Biological Nutrient Removal Wastewater Treatment Systems through on-Line Process Control: A re/View. Rev. Environ. Sci. Bio/Technology 2008, 7, 243-254. [CrossRef]

7. Laureni, M.; Falås, P.; Robin, O.; Wick, A.; Weissbrodt, D.G.; Nielsen, J.L.; Ternes, T.A.; Morgenroth, E.; Joss, A. Mainstream Partial Nitritation and Anammox: Long-Term Process Stability and Effluent Quality at Low Temperatures. Water Res. 2016, 101, 628-639. [CrossRef] [PubMed]

8. Lomas, M.W.; Lipschultz, F. Forming the Primary Nitrite Maximum: Nitrifiers or Phytoplankton? Limnol. Oceanogr. 2006, 51, 2453-2467. [CrossRef]

9. Karl, D.M.; Bidigare, R.R.; Church, M.J.; Dore, J.E.; Letelier, R.M.; Mahaffey, C.; Zehr, J.P. The Nitrogen Cycle in the North Pacific Trades Biome: An Evolving Paradigm. Nitrogen Mar. Environ. 2008, 2, 705-769. [CrossRef]

10. Olson, R.J.; RJ, O. Differential Photoinhibition of Marine Nitrifying Bacteria: A Possible Mechanism for the Formation of the Primary Nitrite Maximum. J. Mar. Res. 1981, 39, 227-238.

11. Guerrero, M.; Jones, R. Photoinhibition of Marine Nitrifying Bacteria. I. Wavelength-Dependent Response. Mar. Ecol. Prog. Ser. 1996, 141, 183-192. [CrossRef]

12. Lomas, M.W.; Glibert, P.M. Temperature Regulation of Nitrate Uptake: A Novel Hypothesis about Nitrate Uptake and Re-Duction in Cool-Water Diatoms. Limnol. Oceanogr. 1999, 44, 556-572. [CrossRef]

13. Mackey, K.R.; Bristow, L.; Parks, D.R.; Altabet, M.A.; Post, A.F.; Paytan, A. The Influence of Light on Nitrogen Cycling and the Primary Nitrite Maximum in a Seasonally Stratified Sea. Prog. Oceanogr. 2011, 91, 545-560. [CrossRef]

14. Collos, Y. Nitrate Uptake, Nitrite Release and Uptake, and New Production Estimates. Mar. Ecol. Prog. Ser. 1998, 171, 293-301. [CrossRef]

15. Kang, D.; Kim, K.; Jang, Y.; Moon, H.; Ju, D.; Kwon, G.; Jahng, D. Enhancement of Wastewater Treatment Efficiency through Modulation of Aeration and Blue Light on Wastewater-Borne Algal-Bacterial Consortia. Int. Biodeterior. Biodegrad. 2018, 135, 9-18. [CrossRef]

16. AWA; WEF. Standard Methods for the Examination of Water and Wastewater, 21st ed.; APHA: Washington, DC, USA, 2005.

17. Kang, D.; Kim, K.; Jang, Y.; Moon, H.; Ju, D.; Jahng, D. Nutrient Removal and Community Structure of Wastewater-Borne Algal-Bacterial Consortia Grown in Raw Wastewater With Various Wavelengths of Light. Int. Biodeterior. Biodegrad. 2018, 126, 10-20. [CrossRef]

18. Merbt, S.N.; Stahl, D.A.; Casamayor, E.O.; Martí, E.; Nicol, G.W.; Prosser, J.I. Differential Photoinhibition of Bacterial and Archaeal Ammonia Oxidation. FEMS Microbiol. Lett. 2011, 327, 41-46. [CrossRef] [PubMed]

19. Bernat, K.; Wojnowska-Baryła, I.; Dobrzynska, A. Denitrification With Endogenous Carbon Source at Low C/N and Its Effect on P(3HB) Accumulation. Bioresour. Technol. 2008, 99, 2410-2418. [CrossRef]

20. Guerrero, M.; Jones, R. Light-Induced Absorbance Changes Associated With Photoinhibition and Pigments in Nitrifying Bacteria. Aquat. Microb. Ecol. 1997, 13, 233-239. [CrossRef]

21. Guerrero, M.A.; Jones, R.D. Photoinhibition of Marine Nitrifying Bacteria. II. Dark Recovery After Monochromatic or PolyChromatic Irradiation. Mar. Ecol. Prog. Ser. 1996, 141, 193-198. [CrossRef]

22. Martínez, C.; Bernard, O.; Mairet, F. Maximizing Microalgae Productivity by Shading Outdoor Cultures. This Work Was Supported by the CONICYT Doctoral Grant (Carlos Martínez), and by the Phycover (ANR-14-CE04-0011) and Purple Sun 
(ANR-13-BIME-0004) Projects. F. Mairet Is Grateful to “FMJH Program Gaspard Monge in Optimization and Operation research". IFAC-PapersOnLine 2017, 50, 8734-8739. [CrossRef]

23. Laureni, M.; Weissbrodt, D.G.; Villez, K.; Robin, O.; De Jonge, N.; Rosenthal, A.; Wells, G.; Nielsen, J.L.; Morgenroth, E.; Joss, A Biomass Segregation Between Biofilm and Flocs Improves the Control of Nitrite-Oxidizing Bacteria in Mainstream Partial Nitritation and Anammox Processes. Water Res. 2019, 154, 104-116. [CrossRef]

24. Rosenberg, E.; DeLong, E.F.; Lory, S.; Stackebrandt, E.; Thompson, F. The Prokaryotes: Other Major Lineages of Bacteria and the Archaea; Springer: Berlin/Heidelberg, Germany, 2014; pp. 733-749. [CrossRef]

25. Prosser, J.I.; Head, I.M.; Stein, L.Y. The Family Nitrosomonadaceae: Berlin, Heidelberg. In The Prokaryotes: Alphaproteo-Bacteria and Betaproteobacteria; Rosenberg, E., DeLong, E.F., Lory, S., Stackebrandt, E., Thompson, F., Eds.; Springer: Berlin/Heidelberg, Germany, 2014; pp. 901-918. [CrossRef]

26. Starkenburg, S.R.; Chain, P.S.; Sayavedra-Soto, L.A.; Hauser, L.; Land, M.L.; Larimer, F.W.; Malfatti, S.A.; Klotz, M.G.; Bottomley, P.J.; Arp, D.J.; et al. Genome Sequence of the Chemolithoautotrophic Nitrite-Oxidizing Bacterium Nitro-Bacter Winogradskyi Nb-255. Appl. Environ. Microbiol. 2006, 72, 2050-2063. [CrossRef] [PubMed] 